\title{
HISTORIOGRAPHY ANALYSIS OF HISTORY TEXT BOOK FROM NEERLANDOCENTRIC TO SCIENTIFIC
}

\author{
Wawan Darmawan'
}

\begin{abstract}
History text book is a historiography work for educational purpose. The historiography exposed in the history text book is definitely different from historiography of another scientific history book. The practical purpose of education becomes one of the important goals of composing the history text book. The history understood from history text book can do more than only developing the student's historical awareness. The historical awareness can be detected in the attitude expressed by the students, such as their sense of nationality, partriotism, unity, willingness to sacrifice, etc. However, the history books composition, including the history text books, cannot avoid the spirit of the period it was written. According to the historiography development in Indonesia, the history text books has been written based on nederlandocentrism, indonesiacentrism, ideologism, and scientific, which are the result of how the spritit of a period affected the history text composition. This research analyse the historiography of history text books that are used in school, especialy in how these history text books appropriately reconstruct historical events with the spirit of a period and how it is composed based on scientific rules of history science.
\end{abstract}

Key words: Historiography, neerlandocentric, indonesiacentric, ideologism, scientifism, narration, description, argumentation, and exposition.

\section{Introduction}

Few years ago (2004) when the KBK curriculum was applied, many history text books for SMP (Junior high school) and SMA (Senior high school) were banned. One of the reasons is that there was a different interpretation in the text book historiography, one of important events in Indonesian history was considered to be inappropariate with the real fact. In another side, historians have to face the fact that there is a criticism toward the construction of Indonesian history they have been built. Bambang Purwanto in his book "Menggugat Historiografi Indonesia" said: "It may be associated with the fact that it had almost been fifty years since the pioneers of Indonesian history text compostition put the philosophical and methodological foundation in Indonesian history, yet the current historiography tradition of Indonesia still has not been able to develop an image as a science that

1 Wawan Darmawan, M. Hum., lecturer at the Departement of History, Faculty of Social Science Education, Indonesia University of Education. This Article has been reviewed by Prof Bambang Purwanto (Gajah Mada University), Prof. Dr. Nina Herlina Lubis (Padjajaran University), Prof. Dr. Helius Sjamsuddin (Indonesia University of Education). 
can be proud of and appreciated as an enlightnent by all people (2005:2). Does the controversy of the history construction cause by the disorder of historical mind set and substantive confussion of Indonesian history? Or, it is not a problem at all because each period has its own characteristic. A particular period will produce a history text composition in a particular color. Historiography is not free of its period influences, can not be separated of the sosio-cultural life of the people supporting it.

Based on the historiography of history text books from the elementary to intermediate level, is the subtantive text relevant with the scienctific rules? The history lesson text book as a historiography work for the educational purpose does not ignore the historiographycal rules of history science. The scienctific rules have to be considered well. The scientific requirements include the source fact, the truth about the fact, the interpretation approach to the fact, the spatial factor, the time factor, etc. Ideally, there has to be a syncronization between the educational mission and the scientific requirements in the historiography of history text books. The historiography development of history text books for high school in Indonesia is interesting to be studied. Therefore, this text will discuss the historiography analysis of history text book in neerlandocentric, indonesianocentric, ideologism, to scientifism, approaching mode, since the independence period to the reformation period in Indonesia. It is interesting to study the development of history text book composition, compared it with the previous historical texts, especially the text composition style.

Another thing which is alsointeresting to bestudied is that in the reformation era many history text book which is currently being used in schools is also stirred by the market. This means, one of the teacher's or school's considerations to use the book is based on the sale profit given by the publisher. This orientation can cause a lower quality of the book, if the teacher or school recomends to use a particular book which has big profit but lack quality.

Helius Syamsudin (2000), in an article, writes about the criteria and the problems of composing history text book. According to him, there are six criteria to be fulfilled in composing history text book:

1. The responsibility to prove the factual subtansion.

2. The interpretation and/or explanation.

3. The presentation and rhetoric must be appropriate with the developmemt psichology theory.

4. The introduction of history concepts (Indonesia and general) needs some criteria.

5. Technically and conceptually, the history text book must follow GBPP (Garis Besar Program Pembelajaran/ the curriculum).

6. Provide informative and narrative illustration, picture, and historical map in the setting and lay out.

The problem of the history text book compostition quality, according to Helius Sjamsuddin, is that there is a clash between the educational goals in one 
side and the profit given by the publishers in another side. This problem sometime pushed the book writer to work faster because the publisher wants to sell the book immediately. There is also a competition among publishers in selling their book in the market.

Said Hamid Hasan (2000), in his article, writes about history text book in the association to curriculum. The topic of his article is how the history text book can adapt with the era development. Hamid found that there are some history text books that have the same content inspite of the change in the curriculum. The book mentions that it is based on the current curriculum. For example, if the valid curriculum is Suplemen Kurikulum 1999, the book will mention that it is suitable for Suplemen Kurikulum 1999 but the content is still based on Kurikulum 1994. This kind of sentence put on the book has something to do with the market perpective. With that kind of sentence on the book, the sale will be higher. Teacher, school, and supervisor will feel save to use a book with that kind of sentence on it.

The text book presentation has a significant association with the learning goal. One of the important factors of text book presentation is how the text book is composed. The modes and approaches use in composing the text books will relate to the materials and goals in the lesson learning.

\section{History Lesson Text Historiography of Neelandocentric Mode}

The term of Sejarah Indonesia (Indonesian History) has been exist since 1942. Before 1942 the history lesson used the terms of Sejarah Hindia-Belanda (Geschiedenis van Nederlands-Indie / Netherlands East Indies History) and Sejarah Tanah Hindia (Indische Geschiedenis / The History of Indies Lands). Most of the source references for history lesson were taken from F.W. Stapel's book, Geschiedenis van Nederlandsch Indie. This book written by Stapel mostly tells about the Dutch's role in Indonesia. Dutch is the main hero in this history text. Indonesian is written as complement or object of the historical story. In Stapel book, the acts of Indonesian is considered as rebellion, if it against the Dutch's policies.

During the Japanese military era, Sujakmoko, quotes from Mohammad Ali, said that propaganda and Japanese institution tried to remove Dutch influences through education by having a strict control in history lesson. Japan changed the term of Indische Geschiedenis into "Sejarah Indonesia (Indonesian History)" (1995:1). Since then, the term of Sejarah Indonesia is known. After Indonesia have their independence, the term Sejarah Indonesia was still used as one of the lesson learned in school, from SD (Elementary school) to SMA (Senior high school). The existence of the history lesson had caused Indonesian History writers to compose books about history lesson. The patriotism and nationalism spirit was explicit in the texts of history lesson, according to the spirit of the era it was written. 
While Stapel's work is neerlandocentric, in the early Indonesia independence era the work of history text tended to be indonesiacentric. This kind of history text was especialized for school. The text books were either written by the teacher it self (in the form of internal lesson text book) or books published legally by the government. However, the source of most of the books is Stapel's, and resulted in an unsatisfying book for the purpose of nationality education.

Moreover, because the reference source was Ducth's (Stafel), thelesson texts still expresses its neerlandocentric side. Neerlandocentric approach is Indonesian History seen from the Dutch's view. In the texts, Indonesia territory is called as Tanah Hindia Belanda (Netherlands East Indies Land) which considered owned by the Dutch. The text exposes a historical story of Ducth activities in Tanah Hindia Belanda (Netherlands East Indies Land). Dutch is the main subject in the historical story, while the native (Indonesian) is only a complement (R. Moh. Ali, 1963).

This mode of text composition can be seen in the works of, such as, Sanusi Pane and Anwar Sanusi. Anwar Sanusi's and Sanusi Pane's works are history text books used in 1960s, although the books itselves were published in 1950 . The books of both writers were the history text book used in school, especially in senior high school. Some of the text lesson quotes from Anwar Sanusi's and Sanusi Pane's works which is more neerlandocentric than indonesiacentric will be explained below.

In the history text book of "Sedjarah Indonesia Untuk Sekolah Menengah II” Anwar Sanusi called the native Indonesian movement againts Dutch's political domination in intervening the authority of native's kingdom as an insurgent movement. The term of insurgent is used toward Makassar troops who helped Trunojoyo fought againts Dutch and Amangkurat I.

Now, Both Kompeni (the term used to address the Dutch, VOC's, soldiers) and Amangkurat I were anxious, they sent their soldiers to destroy the inttruder. But it was not easy to defeat the "djago2 Timur", the soldiers from Makasar (1954: 45).

The main hero of the Indonesian history actor is described in bad character, not considered as an important hero, such as the character of King Amangkurat I.

Then, among Amkurat I's mistresses there was one that he loved very much, her name was Ratu Malang. When the mistress was suddenly died, Sunan had a great grief. He thought that the other mistresses had killed Ratu Malang, Amangkurat ordered to lock up his 43 other mistresses in a castle without food and drink that they all died. And he was looking for Ratu Malang replacement that he found in Surabaya. But, because this future mistress was still under age, she was left to raised by a pungawa, a court administrator. One day, the crowned prince, Pangeran Adipati Anom, saw her and fell in love with her. By the help of his grandmother, Pangeran Pekik, the crowned princess was able to marry the mistress. 
Amangkurat I was really angry when he found out that his future mistress was given away to the crowned prince by Pangeran Pekik. He destroyed the whole family of Pekik, the crowned prince's kingdom was burned down and Pangeran Adipati Anom himself was isolated for a period of time in an island near the south coast (Anwar Sanusi, 1954: 44)

We can also see how the Indonesian kings are described as the ruler who had bad character and appearance, such as King Mataram, Sultan Agung, and Diponegoro, despite that Indonesian addresses them as heroes.

Sultan Agung was handsome with a round face. He had big eyes and he looked to the surrounding like a lion. That was the Dutch's description about his look (Sanusi Pane, 1965: 201)

Dutch's writers had different opinions about Diponegoro's attitude. However, most writers only said the bad side such as arrogant, selfish, rude, and many more. Only one writer who praised him obviously, by saying that he was very handsome, brave, and sincere (Sanusi Pane, 1965: 42)

Futhermore, we can see that the Dutch's role is bigger and more right than Indonesian's.

The Kompeni authority was strengthen by Coen in Banda and Ambon. The people of these two islands often broke the Kompeni monopoly rules. In 1621 Coen went there with 12 ships.

Most people of Banda were dead because they were murdered or hunger. Those who survive were brought to Batavia (including women and children) and became slaves. In half a year most of them were dead. That's the reason why almost all of Banda's people (10. ooo orang) vanished. The population was replaced by slaves, who worked for the Dutch.

The land in Banda was to be divided and given away for the former Dutch soldiers. Because each land section was called "perk", they were called "perkeniers". They planted nutmeg with the help of the slaves. They should only sold the nutmeg to kompeni, but they also sold it illegally to another Europeans, caused them to be rich (Sanusi Pane,1965: 266)

In text above, the role of the Dutch is clear, J.P. Coen as the Netherland Governor-General had an absolute authority to rule people in Banda and Ambon. He had an authority to rule people, the violence he did was not against the law. In fact, he punished the people of Banda and Ambon because they were considered against the law. What Coen did was described as the right thing to do, while what the Maluku people did was wrong. The following text explain that the Dutch (de Kock) did right and legal, which is explained in the story of Diponegoro arresting during the negotiation. Here, Dipenogoro is considered wrong. 


\begin{abstract}
Dipenogoro arrest, which obviously broke the arrangement, was defended by de Kock in his plan to G. G by explaining that truthfully Diponegoro was dishonest because he asked for some requirements, that he knew the Dutch government would not be able to fulfil. Diponegoro increased his troops in Magelang. That broke the arrangement and proved the dishonesty. In his plan de Kock also explained that the Dutch government was willing to end the war because they wanted to protect the Java kings and people (Sanusi Pane, 1965: 73)
\end{abstract}

The history lesson text books written by Anwar Sanusi and Sanusi Pane are not only tends to be neerlandocentric but also indonesiacentric. Indonesiacentric means that all the history events are viewed from the Indonesian perspective and exposing Indonesian as the main heroes in the historical story (R. Moh. Ali, 1963: 125).

\title{
Indonesiacentric Approach Mode of Historiography
}

Composing Indonesian history text in the mode of indonesiacentric emerged as an effort of historiography decolonization. Indonesiacentric history text book put Indonesian as the main heroes in the historical story. Indoesian is the subject of the exposed historical story. According to Sartono Kartodirdjo, et. al., (1977) in Sejarah Nasional Indonesia I, there is some requirements in composing Indonesian history text as a decolonialization effort:

1. A proper Indonesian history is a history which explore "the history from the inside", where the Indonesian itself as the main actor.

2. The Indonesian people development can only be explained clearly by exploring the factor or power influences, including economy, social, or cultural.

3. In a really close accordance with the two requirements above, it needs to explore the activities of various society classes, not only the aristrocracy or knights, but also the Islamic schoolars, peasants, and other society classes.

4. To compose Indonesian history text as a synthesis, which describe a development to the geo-politic unity that we face recently, the integrated principals is needed to measure how far that integration is achieved in a particular period.

Based on theproblemofthehistorytextbookwhich was notindonesiacentric, a seminar called Seminar Sejarah Nasional (14-18 December 1957) was held in Yogyakarta. The topics discussed in the seminar are as follows:

1. Philosophical concept of national history.

2. The periodisation of Indonesian history.

3. Compostition requirements of Indonesia national history text books.

4. Indonesian history teaching in schools.

5. Historian education.

6. Historical materials education and teaching (PPIS-LIPI (1976). 
The seminar's topic is clearly contraproductive with the previous neerlandocentric history text compositions and the indonesiacentric in forming the nation personality. This study will historiographycally analyze the history text book written by Soeroto, Soendhoro, and lesson text book written by Notosusanto which show the indonesiacentric side.

In 1965 Soeroto wrote a book in the tittle of "Indonesia Ditengah-tengah Dunia Dari Abad Keabad". From the tittle we can conclude that this book is more indonesiacentric by viewing Indonesia position in its relation with other countries. Take a look the following text.

When Indonesian stepped into the history, they immediately got contact from other countries. It was not strange at all because Indonesia is in the middle of the world. The world at that time was Asia. Indonesia's position was in the middle of the sea tour that connects Tiongkok (China) and India. It could be estimated that we had contact with India and Tiongkok. This contact had been begun since the early Christ era, maybe even earlier (1965: 107)

In the contratry with the book of Anwar Sanusi and Sanusi Pane, Soeroto's book does not expose the Dutch as the main actor of Indonesian history in their colonization era in Indonesia. Indonesian is not a history object in the colonial era. Soeroto refuses the opinion that Indonesia was colonialized by the Dutch for three and a half century. Soeroto describes the Dutch with a bad character. J.P. Coen was a violant person. Trading monopoly by the VOC was not applied all over Indonesia, it was only applied in Jakarta, Ambon, and Maluku (1965: 191-192).

Soendhoro's book also has the same characteristic. His book was published in 1973 with the tittle of Sejarah Indonesia, S.M.A. The book was published based on the application of Kurikulum Gaya Baru 1964 (New Style Curriculum of 1964). Based on the periodicalization composed by Soendhoro, the composing style is also indonesiacentric. Indonesian is the main hero in its own history, colonialization is considered as suppression. In his book Soendhoro mentioned that Indonesia is a nation with history, which is sejarah tanah air (the history of fatherland).

Our country has history and pre-history. The investigation sources of this father land history are including the written stones, written reports from Chinese and Arabian travellers, ancient books and reports from a Venetian, Marco Polo, who had been living for a long period in Tiongkok (1973: 5-6)

The various ethnics in Indonesia were described by Soendhoro not as a differentiation, but as a unity. According to Soendhoro, the Indonesian lived in Indonesia islands are not a native people, but their ancestor are the same. Their ancestor came from North Yunan (South China). This ethnical diversity is the symbol of "bhineka tunggal ika (unity in diversity)" (1973, 8-11). Still in the same 
chapter, Indonesian has been considered as a good people since the pre-historic era (1973:14).

In the pre-history era Indonesian people had already lived in an orderly society. Their way of life was signed by the gotong-royong (a concept of mutual cooperation). All of the society felt the pain and happiness together as one. Individual ownership was not known. The land surrounding a village was the society account and was managed in gotong-royong. A big house made of wood was the house for the whole villagers. Anything concerned with the society or individual was managed in gotong royong.

The book is not neerlandocentric. Dutch and its VOC are considered as a violence nation toward Indonesian in their efforts to do the trading monopoly in Indonesia, such as Hongi sailing and the right to extirpate.

Since Coen ruled, he managed the monopoly in Indonesia in violence. Maluku suffered the most. The people of Maluku were not allowed to trade with another country. Trading with another country was considered as a violation of VOC monopoly rules, considered as an illegal trading. The consequences were expropriation, confiscation, and serious punishment. That was why the native suffered badly (1973: 93).

Soendhoro did the same thing when he explained Indonesian history at the period of Politik Etis (etichal politic) as the period of "the rise of Indonesian". When he wrote about Japanese era, Soendhoro also wrote about the removal of feodalism which was maintained well during the Dutch period. The Japanese military government was able to develop a discipline habit for Indonesian which was used as a tool to fight for Indonesia's independence. Take a look at the following text.

If the previous era (the Dutch colonial era) feodal system was really applied and maintained that the aristocrat class can do whatever they want, in the Japanese era the society classification was removed. Every Indonesian was citizen. This mean that every Indonesian was blended and they would feel equality, feudalism was removed. This resulted in the people confidence. They were encouraged to do something, to reach independency. The misery, torture, and disciplinary suffered by Indonesian in Japanese era was a strong capital and foundation for the next Indonesian struggle (1973: 53-54)

Buku Paket Sejarah Nasional Indonesia jilid 1, 2 dan 3 untuk SMA written by Nugroho Notosusanto is based on the six volumes of Sejarah Nasional Indonesia (Indonesia National History, the Babon book). According to the tittle, its indonesiacentric side is very explicit. Indonesian role, since the pre-historic period to its relationship with the world is explained clearly in this book. Take a look at the following text. 
We should be proud that the ancient people that was discovered in Indonesia is an important discovery. Indonesia is a place in Asia which has many ancient people discovery. Since the 18 century experts from abroad have been interested in doing some research about ancient people in Indonesia. They keep coming to Indonesia. The first researcher that came to Indonesia was a Dutch doctor named Eugene Dubois.

Indonesia is really lucky, not only because it is a place of ancient people discovery which is very rare, the discovery also has various kinds. This proves that various ancient people had lived in Indonesia. They were probably had lived from generation to generation. Or several species who lived in the same period (Nugroho Notosusanto, 1981: 15-16)

The Indonesian geographical condition which most of it is water area has formed Indonesian as a great sailor. This characteristic of Indonesia's area had helped Indonesian to interact with another nation in the past, such as China and India. Indonesian is in an active postion.

Since the pre-history era, Indonesian people had been known as sailors who were able to conquer the ocean. The sea surrounding and in between islands was not an obstacle to made contact with each other. It even became a unification factor (1981: 57-58).

Indonesian also had a great role in the past, since the Islamic period to the colonial period. As in Soeroto and Soendhoro books, the western (Portuguese and Dutch) is described as a violence nation. They were colonialist, greedy, selfish, and unfriendly, pretty much like Portuguese.

The greedy attitude of Portuguese, who forced spices trading monopoly, caused the people of Maluku and another area disliked them. Besides economy, the Portuguese in Maluku was disliked because of religion. They were always forced their religion to the native, besides forcing the trading monopoly (Nugroho Notosusanto, 1981: 125)

The bad attitude had also been shown by the Dutch since the very first time they arrived in Indonesia.

At the beginning the Dutch showed a friendly attitude and made an arrangement with Banten. The trading relationship had been smooth. But at the end the Dutch showed its greediness and selfishness. This caused Banten people to hate them and the Dutch had to step aside (Nugroho Notosusanto, 1981: 126)

The politic-economy policy of Dutch colonial is mostly described as an act which caused Indonesian people to suffer. Dutch had taken most of the benefits, whereas Indonesian suffered because of, for instance, Tanam Paksa (Cultuurtstelsel/cultivation system) and in the period of Western private investation in 1870 until 1900. 
The cultuurstelsel direct impact for Indonesian was quite obvious. Poverty, devastation, and hunger were the bad destiny that has to be suffered by the native because of the cultuurstelsel system. The big tax, crop failure, and slavery had brought a misfortune in various places (Nugroho Notosusanto, 1981: 183)

The lesson text book is not only explained the political event, but also explain about the social history, such as the history of "orang-orang kecil (common people)". The term of "orang-orang besar (important people)" is for political history, such as the role of the kings, nation, power, etc. The "orangorang kecil (common people)" written in this lesson text book is also had a big role in fighting against Dutch colonial.

In facing the West authority effect that brought misery to the life, the villager had their own way to fight, which was by social movement. This social movement was a movement to oppose or to protest the authority, both the colonial government and the local authority that was considered to cause the misfortune. The movement was simple. These movements were not properly organized like a modern movement organization. Their fight was not based on any plan or program (1981: 198)

\section{Ideologism Approach Mode of Historiography}

History lesson is a lesson associated to the nation's character development. This results in the goal of history lesson to be associated to the state political ideology. The state mostly viewed that the nation character formation of its citizen is the state's responsibility. This obligation is done through education, including the history lesson. This means, the goal of history lesson is ideological (Agus Mulayan, 2009).

The ideologism in this discussion means the historiographical approach applied in PSPB (Pendidikan Sejarah Perjuangan Bangsa/Education of National Struggle History) which composed an ideological history text is a searching of the subjective meaning of historical events. The past is learned not for the knowledge about the past but for the symbol to be presented in the present time. History is the best teacher who can teach how to avoid mistakes that had happened in the past. The value emphasized of the history is the educative value (Taufik Abdullah \& Abdurrahman Surjomihardjo, 1985:29).

The term ideologism uses here is for the purpose of analysing the Pendidikan Sejarah Perjuangan Bangsa (PSPB) text book. I view the PSPB lesson as an ideological interest of the goverment (Orde Baru). The emergence of PSPB lesson was determined by Ketetapan MPR (parlemiantary determination), TAP MPR No. II/MPR/1983. The law foundation of PSPB lesson is different from other lessons, which usually determined by Keputusan Menteri (ministry determination). 
In the curriculum structure, PSPB was an individual lesson. However, the lesson material was taken from History lesson. PSPB lesson material took particular themes that were considered able to develop a fighting spirit or patriotism for the students. This means the history of the past was used as a tool to develop national ideology in the government's version, which was Orde Baru goverment.

The book analysed for the PSPB historiographycal is "Sejarah Nasional Indonesia Untuk SMA Jilid 3" edited by Nugroho Notosusanto, which also called "Buku Paket (Lesson text book)". The book is one of the references for PSPB lesson other than 30 Tahun Indonesia Merdeka, before a particular book for PSPB lesson was available. The ideological approach can be seen clearly in the book by the sub title of "Mengingkari Nilai-Nilai 1945 (Denying the 1945 Values)" and "Menyelewengkan Dari Cita-Cita 1945 (Betray the 1945 Hopes)". Furthermore, the sub title of "Percobaan Sistem Politik Demokrasi Liberal (Trial of Liberal Democration Political System)" and "Sistem Ekonomi Liberal (Liberal Economy System)" was interpreted as a betrayal to the 1945 values. Whereas the sub title of "Sistem Ekonomi Terpimpin (Guided Economy System)" and "Politik Luar Negeri Nefo-Oldefo (Nefo-Oldefo Foreign Politic)" were interpreted as the betrayal of the 1945 hopes. Orde Baru was written to be the emergence of an order which tried to fix the failure happened in the past.

Orde Baru was a total correction of deviation in every field that had happened in the past, and tried to rearrange the nation's power and inventing the correct ways to develop the long term national stability, to accelerate the Nation's development process based on Pancasila and Undang-Undang Dasar 1945 (Nugroho Notosusanto, 1987: 173)

\section{Scientific Mode of History Text Book Composing.}

The history lesson is a lesson considering the importance of text composing. The text composition factor of the history is very important, because a text composition gives a description on how an event is constructed and understood. The construction and understanding of an event written in the text book has to be associated with the teaching goal.

In one side the history teached in school is the history as knowledge. The implication of this aspect is that history has to follow scientific rules of science. The scientific of history expresses in how the history is composed (historiography). The history text composition mode follows the science developments, which are the development of history methodology and theory. Therefore, the text book composition is scientific.

Different from the ideologically history compostion which emphasized the education of value, or we can say that there is an ideological indoctrination to the student, the new history in the teaching practice can develop the student logical 
power. It can develop a critical attitude in the student character. Moreover, the historical events will more be approached from the structural aspect. This kind of approach can expose the analitical and sinthetical way of thinking. Peter Burke (1995:2-6) mentioned the new histroy characteristic as follows.

1. History emphasizes every human activity.

2. Histoy is composed in a structural analysis.

3. Compose about the "lower people" or the common people and their social shift experience.

4. The history source is not only document, but we can also use another source such as spoken source.

5. History objectivity is not based on documents, but also on the researcher's thinking frame.

According to these requirements, it is clear that history text composition actually develop with the science development.

Theoritically the senior high scholl history lesson text analyzed is divided into two parts, chronological and thematical, which provide the characteristics defined by Peter Burke. Not all of the study result sample will be provided here, only one of them will be explained.

\section{Chronological Approach Mode}

Chronological approach mode is one of the modes or general pattern which orientation is to history teaching materials organization as a development based on time order of the historical events. The historical events are organized or programmed orderly from the pre-historic period until the contemporary history. In this mode of history material development, consentric spiral mode can be provided to discuss the higher, deeper, and wider historical events. The characteristic of chronolical mode of material development is based on the year of the historical event.

History is a study of human life in the context of time. Periodisation is provided to simplify our understanding about what had happened in human life. Periodisation is provided to simplify the explanation about human development from time to time. Periodisation is a kind of serialisation of various historical events based on time period order. Thereby, the periodisation concept which is appropriate to organize historical events is chronological mode. By chronological mode of periodisation we can provide the characteristics of human life in each period of time and an event will be easier to be understood as a whole.

Periodisation will explore the development of human life, the continuity from one period to another, and the difference from one period to another. Based the study of chronological mode in, for example, historical material of senior highschool grade 2, we can explore the period of national movement. Internally, Indonesia nationalism is the effect of education provided by the Dutch's colonial 
government for the native (the Etical Politic had begun in 1901). This education, infact, emerged a new class in Indonesian, the intellectual and literate people. These people were aware that they had been colonialised, and this awareness had grown a hope to free the nation from the colonialist and a desire to develop a national country. There was a change in facing the colonialist. Before the twentieth century, there were more physical fights against the colonialist, such as Diponegoro War, Paderi War, Aceh War, and others. When the national movement which led by the intelectual people was emerged, the fight had shifted to using modern organization.

Periodisation organization depends on what kind of history will be written. Periodisation can be oraganized based on the political development, socialeconomy development, cultural development, religion development, and more. The political development, for instance, compose the periodisation of ancient kingdoms or dynasties. In the material for junior highschool and junior highschool grade 1, the explanation of Indonesian ancient kingdoms is explored from the period of Hindu-Buddha kingdom until the period of Islam. The Hindu-Buddha kingdoms period is explained from the oldest kingdom, Kutai, to Majapahit. The end of Majapahit period was the early period of Islam kingdoms. Each of these kingdom periods provides an explaination about the kings' authority, especially those who had an important role.

The social-economi periodisation can be seen in senior high school grade 1 materials. The materials explore about the development of human life from the period of hunting, gathering food, early planting, farming, to the production period. Each period has its own characteristic. For instance, the hunting and gathering food period is a period when human still depends on the nature. Human depends on the nature to provide their needs. The social life in the hunting era was in group and nomadic. In the farming period, human began to stay in a particular area because they were able to manage the nature by farming. They did not depend their social-economy life to the nature anymore. There was a production process, though it was really simple.

Based on the chronological theory, the result of historiography analysis is that chronological approach has been used in the senior highschool lesson material for grade 1 to grade 3 . The continuity of chronological approach is exposed in several materials. Continuity means that there is continuity between one historical fact or event to another. For instance, it can be seen in grade 2 lesson material about Hindu-Buddha kingdom in Java, especially in Ancient Mataram kingdom to Majapahit Kingdom. The Ancient Mataram kings, started from Sanjaya and Syailendra Dynasti, Singasari Kingdom, and Majapahit Kings had a genelogical connection. Generaly, every effort to take over an authority in the kingdom results separation. The separation could result in two things. First, an authority conflict happened in the kingdom. The new king in power is the winner of the conflict. Second, the separation resulted in a new kingdom. The first case can be seen in Singosari Kingdom. This kingdom was established by Ken 
Angrok (read: Ken Arok) after killed Tunggul Ametung, an Akuwu (mayor) in Tumapel. What he did had resulted revenge by Tunggul Ametung son, Anusapati. Ken Angrok was killed by Anusapati. What Anusapati did also result revenge from Ken Angrok's son, Panji Tohjaya. Panji Tohjaya became a king in Singosari after killed Anusapati.

If we analysed the history lesson material in senior high school historiographycally, there is a factual chronological explaination. Many factual materials are in the grade 3 senior high school text books, especially the material of Early Independence to Orde Baru period. The chronological order of the politic events includes inner state security disturbances, such as DI/ TII, PRRI-PERMESTA, RMS, etc. In the period of Demokrasi Terpimpin (guided democration) there is an explanation about the Dekrit Presiden 5 Juli 1959 (President Decree 5 July 1959) and Pelaksanaan Demokrasi Terpimpin (Guided Democration Implementation). The Orde Baru era started with Gestapu, Supersemar, MPRS conference, and the born of Orde Baru Government. Below is a quotation of High school grade 3 lesson material in E-book which apllied the chronological approach.

The parliamentary government system which based on the UUDS tahun 1950, did not bring any political stability. Since 1950-1955 there had been four cabinets restructuring, which mean every year had a cabinet restructuring. In liberal democracy era, Indonesia had seven cabinet restructurings and prime ministers:

1. Muhammad Natsir (Masyumi) from September $6^{\text {th }} 1950$ until April $27^{\text {th }} 1951$;

2. Dr. Sukiman (Masyumi) from April $27^{\text {th }} 1951$ until march $3^{\text {rd }} 1952$;

3. Wilopo (PNI) from March $3^{\text {rd }} 1952$ until August $1^{\text {st }} 1953$;

4. Ali Sastroamijoyo (PNI) from August $1^{\text {st }} 1953$ until August 12 ${ }^{\text {th }}$ 1955;

5. Burhanuddin Harahap (Masyumi) from August $12^{\text {th }} 1955$ until March $24^{\text {th }} 1956$;

6. Ali Sastroamijoyo (PNI) from March $24^{\text {th }} 1956$ until April $9^{\text {th }} 1957$;

7. Ir. Juanda (no party) from April $9^{\text {th }} 1957$ until July $10^{\text {th }} 1959$.

\section{Thematical Approach Mode}

"Thematical" mode is a mode to develop history teaching material. This mode develop various people life themes which is use to develop a particular potential, such as values for individual potential, social potential, intellectual, emosional, religious, or to be centered to what interest the student. Generaly, the lesson materials are grouped in a particular theme including politic, militer, social, economy, cultural, intelectual, education, etc.

For instance, the politic theme usually explains the things associated with authority. In a politic power there are various components, such as the ruler or government, administrative system, parlement, law, politic party, state, kingdom, 
etc. Historical text composition which includes those components is generally in the politic theme.

Based on the research in senior high school history text books, we can see a political theme history exposing various people who are considered as "orangorang besar (important people)" such as Hitler, Hirohito Emperor, and Mussolini, when discussing about World War I and World War II. What those people did really affect the world. The war would have not happened if those people not intended to do it. Because of their power the world entered the World War II.

In another historical text we can find another political theme, including the rise and fall or the change of the old dynasties. The dynasty changing is more because of the king's behaviour itself. The history text composition about the Hindu-Buddha and Islam kingdoms period is clearly seen from political perspective.

Military theme history can be defined as a text about the army and the war behaviour. Various things can be discuss about the history of war, including the strategies, the troops' power in the war, and the weapon. In a war history text, the discussion is not only about military operational aspect. War history can be seen through various factors, economy for instance.

The Indonesian history in the text book for senior high school grade 2, military theme is the main theme to be discussed. One of the themes is the period of VOC arrival. VOC activities in Indonesia included wars. As a trading partner company, VOC had an authority to fight its enemies. VOC and its wars could rule and colonialize Indonesia.

VOC had war technology and strategy. The bigger ship armed with modern weapons that VOC had at that time is well discuss in the lesson material of Colonialism and Imperialissm in Indonesia. The maritime and war technology that VOC had was more advanced than the native had. The VOC trading business was done in war. In this method VOC can rule the water area of Nusantara.

In studying the war history, the focus is not only about weapons. War will succeed if it is supported by another factor, such as logistic. This can be seen in the war between Mataram, in the era of Sultan Agung, and VOC. Sultan Agung as the king of Mataran sent his troops to Batavia (Jakarta). Mataran lost in this war against VOC. VOC burned down Mataram's food logistic store room in Karawang. This way, Mataram logistic went weaker. Below is a quotation from history lesson material for senior high school grade 1.

Mataram kingdom was established in the 16 century by Senopati (Sutawijaya) (1586-1601). The central was in Yogyakarta. He had a dream to unify Java under his authority. In order to do that he expanded his authority to Demak, Madiun, Kediri, Ponorogo, Tuban, and Pasuruan. But that dream had obstacles in another region and Surabya, those regions could not be conquered.

After Senopati died in 1601, he was replaced by his son Mas Jolang. After Mas Jolang died, the kingdom crown was given to his son, Raden 
Rangsang, who is known under the title of Sultan Agung (1613-1645). He was the greatest Mataram king in the history. The entire Central Java and East Java, including Madura, had acknowledged Mataran sovereignty. Surabaya that was hard to be conquered could be conquered in Sultan Agung era in 1625. In West Java, Mataram authority was including Cirebon, Sumedang, and Ukur (now Bandung). Banten could not be conquered.

The thematical study in economy can be discussed in a wider scale, the national, regional, or international scale. Indonesian economy history for junior higschool and senior highscool grade 2 can be found in the lesson material about the colonialism period. The arrival of colonist in Indonesia mostly associated to the trading activities in Middle Sea that follow a route in Malaca Strait. The purpose of the Western people visit to Indonesia always had relevance with spices, and finally the colonialist had Indonesia opened for an open economy. Below is the example of a history material in economy theme.

The colonialism process that was centralized in the East, especially in Indonesian Islands, was basically affected by the economy, social, and politic condition in the West at that time. Some factor that supported the colonialism development in Indonesian Islands includes the rising of Mercantilism, Industry Revolution, and Capitalism movements. In another side, there was one thing that had a very important role for the European Colonialism development, Constantinople as the East Rome capital city was conquered by the Ottoman Empire in 1453. Because Constantinople was conquered by the East, the trading around the Mediterranean Sea and West Asia was dominated by Turkish. At that time, many European merchants were disadvantaged by the trading rules of Turkish. This had caused many European merchants to find their own way to the East in order to find commodity, including spices that were in demand in the European market.

There are many more themes in composing a history text, such as demography, psychology and psychoteraphy, education, ethnic, family, and many more. After analysing the history text book for junior high school and senior high school, it can be concluded that the social history theme is closely associated to the people life; economy history is closely associated with economy modes or theories; politic history is closely associated to political activities; education history is associated with thinking tradition, while the great thinkers in education are not mentioned in the text books. Furthermore, if it is associated to the material development strategy, some of the material explaination in the text book uses various themes. For instance, Proclamation can be seen from the perspective of politic, military, economy, social, and cultural. 


\section{Text Composition From}

Based on the historiographical analysis, the scientific historical text composition can be categorized in four forms, narration, description, argumantetion, and exposition.

\section{Naration}

Naration is a historical text composition that only exposed the time order, the events serial from the beggining until the end of the story. This mode of text composition is similar with chronological history composition, which exposes the time order of the events. This historical material in narration text can be seen in the history lesson material for junior high school and senior high school. In the material for senior high school level, the narration is more detail and comprehensive, including the Arrival of the Western into Indonesia (Grade 2), Independence Proclamation (Grade 3), Indonesia Independence War (Grade 3), and The War to Return Irian Barat. Below is an example of narration text composition for junior high school grade 1.

The Spain Cruiser who had a big role in finding a direct route to Maluku Islands was Ferdinand Magelhaens (1480-1521). Magelhaens started to cruise to the southwest, following the route of Christopher Columbus's (an Italian who devoted himself to the Spain King and made his way to the America Continent that he believed as India), crossing the Atlantic Ocean to the south end of America. From there he moved to west, crossing the Pacific Ocean and arrived in Philippine Islands (1521). There, in Cebu Island, Magelhaens was killed by Mactan tribe. The cruise to Maluku Islands was continued by Juan Sebastian del Cano. Their arrival caused a rivalry with Portuguese which was ended by signing the Saragosa Agreement (1534). The agreement mentioned that the Portuguese's authority stayed in Maluku, while Spain's stayed in Philippine.

\section{Description}

Description is a text composition to describe a particular historybackground in a particular period. By description text composition the student is guided to see, to listen, to feel, and to be heard by the history writer. In practice, description sometimes is combined with narration, argumentation, and exposition. Based on the text study result, most of descriptive material is the material for senior high school, including the development of western colonialism and imperialism which is described with the background of economy, politic, cultural, and religion. It results in a wider discussion. Actually, if it studies deeper, most of event explanation in the history is described, not narrated. Through description the discussion will be deeper and wider. 


\section{Argumentation}

Argumentation is a history text composition aimed to convince people, to prove an opinion, or to persuade people to accept an opinion. Below is an example of argumentation history text composition in the lesson material for senior high school grade 1.

The trading relation between the Indonesian merchants and India merchants resulted in the Hindu-Buddha tradition influencing the Indonesian culture. There are two theories that explain about when, who and how the Hindu-Buddha tradition entered and spread its influences in Indonesia, the colonization theory and noncolonization theory ...

According to colonization theory, the spread of Indian tradition to Indonesia was brought by the ksatria and waisya class. Jl Moens said that the war between Indian's kingdoms had caused the ksatria class to come to Indonesia. They were the soldiers (ksatria) who runaway or refugees after the war lost. One of their refugee destinations was Indonesia...

\section{Exposition}

Exposition is a history text composition to give information, explanation, and understanding about a historical event in a particular time and location. Based on the study of the text book for junior high school and senior highschool, this type of text compostition is rarely exists. Most of the text compositions are in narration, description, and argumentation. There is a book based on the Kurikulum 2004 which the text compostition tends to this expostition text. Below is a quotation about islamisastion process in Indonesia (senior highs chool grade 1).

... since the beginning of Islam expansion, education was very important as an effort in the Islam spreading process. That resulted in the development of a simple education system, halaqah. At the beginning the religion education occurred in a mosque or small prayer house. Mosque, besides as a place to pray, it was also a place to conduct the religion education. The lesson was about reading Al-Quran, praying manners based on Islam Pillars, moral, and faithf.

\section{Conclusion}

The history lesson is a lesson considering the importance of text composing. The text composition aspect of the history is very important, because a text composition gives description on how an event is constructed and understood. The construction and understanding of an event written in the text book has to be associated with teaching goals. History lesson is a lesson associated to the development of the nation's character. Furthermore, the history lesson text composition is also influenced by the spirit of a period. Therefore, no wonder if the text composition shifts from neerlandocentric, indonesianocentric, ideoligical 
and scientific which is influenced by the development of knowledge, methodology, and history theory. The implication of these factors is that history has to follow scientific rules of science. The scientific of history expresses in how the history is composed (historiography).

\section{REFERENCES}

Abdullah, T \& Abdurrachman, S. (1985). Ilmu Sejarah dan historiografi Arah dan Perspektif. Jakarta: Gramedia.

Ali, M. (1963). Pengantar Ilmu Sedjarah Indonesia. Djakarta:Bhatara

Ali, M. (1995). :Beberapa Masalah tentang Historiografi Indonesia”, dalam Soedjatmoko, ed., 1995. Historiografi Indonesia sebuah Pengantar. Jakarta: Gramedia

Badrika, I.W. (1996). Sejarah Nasional Indonesia dan Umum untuk SMU Kelas 1,2, dan 3. Jakarta: Erlangga

Burke, P, Ed. (1991). New Perspektives on Historical Writing. Cambridge: Polity Press

Darmawan, W. (2004). Cakrawala Sejarah untuk SMA Kelas 1,2, dan 3. Bandung: Sinerji Pustaka Indonesia

Hasan, S. H. (2000). ' Kurikulum dan Buku Teks Sejarah, dalam Historia, No. I. Vol. I, tahun 2000. Bandung: Jurusan Pendidikan Sejarah FPIPS UPI

Kartodirdjo, S. (1982). Pemikiran Perkembangan Historiografi Indonesia: Suatu Alternatif. Jakarta: Gramedia

Kartodirdjo, S. (1983). Dalam Anthony Reid\& David Marr, ed . Dari Raja Ali Haji Hingga Hamka Indonesia dan Masa Lalunya. Jakarta: Grafiti Press

Keputusan Menteri Pendidikan dan Kebudayaan Republik Indonesia No. 0264/ $U / 1985$

Kurikulum Tahun 1964.

Kurikulum SMA Tahun 1968.

Kurikulum SMA Tahun 1975.

Kurikulum SMA Tahun 1984

Kozicki, H, Ed.(1993). Development in Modern Historiografi. London: Macmillan Press

Klooster. (1992). History and Social Theory. Cambridge: Polity Press

Klooster. (1985). Indonesiers Schrijven Hun Geshiedenis: de Ontwikkwling van de Indonesische Geshiedbeofening in Theorie en Praktijk, 1990-1980. Dordecht-Holland, Cinnaminson-USA: Foris Publication

Llyod, C. (1998). Explanation in Social History. Cambridge: Blackwell (1993). The Structures of History. Cambridge: Blackwell

Mulyana, A. dan Tarunasena. (2004). Memahami Sejarah SMA untuk Kelas X, $X I$. Bandung: Armico

Notosusanto, N. ed. (1980), Sejarah Nasional Indonesia Untuk SMA Jilid 1, 2, dan 3, Jakarta : Depdikbud. 
Pane, S. (1965), Sejarah Indonesia Jilid I dan II, Jakarta : Balai Pustaka.

Poesponegoro, M.D. \& Nugroho Notosusanto, (1984), Sejarah Nasional Indonesia I, Jakarta : Balai Pustaka.

Sanusi, A. (1952), Sedjarah Indonesia Untuk Sekolah Menengah Jilid I dan II, Bandung : Pustaka pakuan.

Sjamsuddin, H. (2000). "Penulisan Buku Teks Sejarah: Kriteria dan

Permasalahannya", dalam Historia, No. I. Vol. I, tahun 2000. Bandung: Jurusan Pendidikan Sejarah FPIPS UPI

Soendhoro. (1966). Sejarah Indonesia Jilid I dan II, Jakarta : Mutiara.

Soeroto.(1955).Indonesia Ditengah-tengah Dunia DariAbad Keabad Peladjaran

Sedjarah untuk Sekolah Menengah 1, 2, 3, Jakarta : Djambatan.

Stapel, F.W, Ed., (1938-40), Geschiedenis van Nederlandsch-Indie, Amsterdam. Supriatna, N. (2003). Sejarah untuk SMU Kelas 1, 2, dan 3. Bandung: Grafindo 